\author{
Yaroslav Kornienko and Roman Sachok
}

\title{
COMPLEX ASSESSMENT OF THE EFFICIENCY OF GRANULATION PROCESS IN DISPERSED SYSTEMS
}

\author{
National Technical University of Ukraine "Kyiv Polytechnic Institute" \\ 37, Peremohy Ave, 03056 Kyiv, Ukraine, che@ users.ntu-kpi.kiev.ua
}

Received:April 04, 2008

\begin{abstract}
The methodology of complex assessment of the dispersed composition of the granulated product obtained during granulation from liquid systems for various types of humic and mineral solid composites has been offered. A complex assessment of the granulation process efficiency by granulation coefficient and the quality degradation of the granulated product dispersed composition function has been offered.
\end{abstract}

Key words: dispersed composition, granulation coefficient, quality degradation function, humic-nitrogenous, humiccalcic-nitrogenous, humic-calcic-potassic-nitrogenous multilayer solid composites.

\section{Introduction}

More than $8 \%$ of the world supplies of chornozem soil are found in Ukraine. However, due to systematic violation of the scientific management principles their fertility decreases catastrophically, that is why the problem of the soils' fertility preservation is of great importance for Ukraine.

The increase of negative influence of technogenic and anthropogenic nature on soil genesis calls for the new approaches to creation of organic-mineral complexes, whose application would be conducive to preserving the ecological balance in land use.

The authors [1] have offered the method of obtaining humic and mineral fertilizers using the fluidized bed technique in the form of multilayer crystalline amorphous solid composites with variable ratio of nutrients and stimulants, which is defined by agricultural and ecological requirements to the application region.

The formation of solid composites from liquid systems with the components equipartition throughout the volume of the sphere-like granules of the size of 1.5+4.5 $\mathrm{mm}$ and the hardness of minimum $15 \mathrm{~N}$ per granule is a complex multifactorial process.

It was experimentally [2] established that the generalized process efficiency was determined by the granulation coefficient

$$
\psi=\frac{G_{G}}{G_{M}} \cdot 100
$$

where $G_{G}$ is the mass productivity by granulated product, $\mathrm{kg} / \mathrm{s} ; G_{M}$ is the dry substance mass supplied to the granulator with the liquid phase, $\mathrm{kg} / \mathrm{s}$;

Here, however, the dispersed composition of the obtained granulated product which specifies its quality is not taken into account. Naturally, this characteristic can be dependent on the chemical composition of the humicmineral fertilizers.

\section{Experimental}

Granulation research of the humic-nitrogenous ( $\mathrm{H}: \mathrm{N}=1: 20)$, humic-calcic-nitrogenous ( $\mathrm{H}: \mathrm{Ca}: \mathrm{N}=1: 12: 15)$, humic-calcic-potassic-nitrogenous ( $\mathrm{H}: \mathrm{Ca}: \mathrm{K}: \mathrm{N}=1: 5: 8: 15)$ composites from liquid composites systems was conducted in the fluidized bed unit of the size of $0.1 \times 0.3 \times 1.2 \mathrm{~m}$.

It was experimentally established that the technological conditions under which the particles dispersed composition in the fluidized bed met the requirements to the finished product: $90 \%$ of the granules per mass have the size of $1.5-4.5 \mathrm{~mm}$.

The function of the predetermined mass distribution of the finished product in the form of normal distribution is represented as the shaded area in Fig. 1. This enabled implementing the granulation of the humicmineral solid composites in the fluidized bed without separation extraction of the finished product from the unit.

The quality assessment of the granulated product's dispersed composition was conducted by means of mathematical function of quality degradation suggested by prof. Tahuchi [3].

The general view of the quality degradation function of the granulated product is as follows:

$$
\begin{aligned}
& L=b_{d}\left(\frac{d_{e}-d_{e s t}}{d_{e s t}}\right)^{2}+b_{\sigma}\left(\frac{\sigma-\sigma_{s t}}{\sigma_{s t}}\right)^{3}+ \\
& +b_{a}\left(A s-A s_{s t}\right)^{2}+b_{e}\left(E k-E k_{s t}\right)^{2}
\end{aligned}
$$

where $D_{e}, \sigma, A s, E k$ are the current values of the particle equivalent diameter in the fluidized bed, mean-square deviation, asymmetry, and excess of the granule mass 
distribution in the unit, $d_{e s t}, \sigma_{s t}$ are the corresponding parameters of the predetermined dispersed composition of the finished product [4].

The minimum value of the $L$ function specifies the process which makes it possible to obtain a quality granulated product.

During the series of the experimental researches the dispersed composition was being defined every $20 \mathrm{~min}$. The duration of the experiment was 12.33 h. Figs. 1a, b and $\mathrm{c}$ represents the mass distribution under the dimensionless time values for three types of the humicmineral fertilizers by the following expression:

$$
\bar{\tau}=\frac{\tau_{i}}{\tau_{p}}
$$

where $\tau$ is the current time value at which the dispersed composition in the fluidized bed was defined, $s$; $\tau_{p}$ is the total time of the experiment, $\mathrm{s}$.

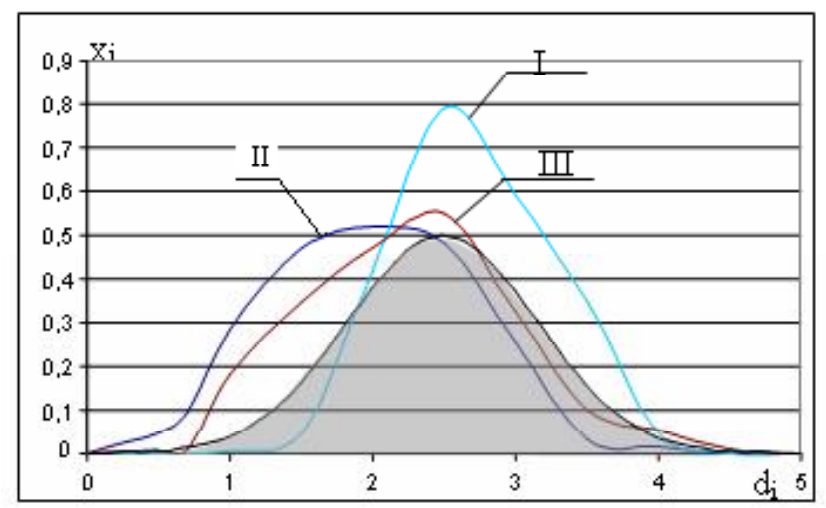

a

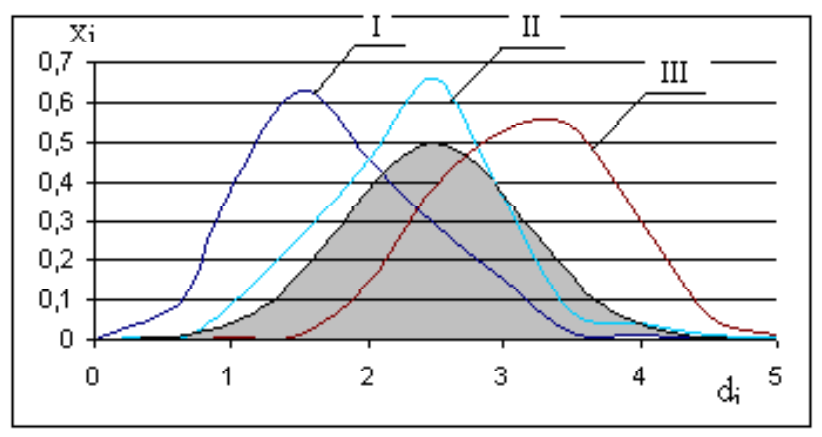

b

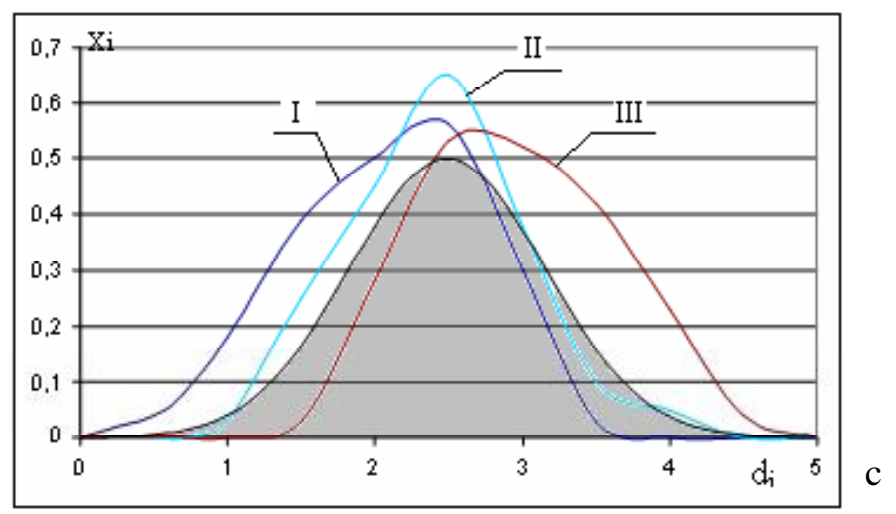

Fig. 1. The mass distribution of multilayer solid composites of different composition by diameter: for humic-nitrogenous multi-layer solid composites ( $\mathrm{H}: \mathrm{N}=1: 20)$ (a); for humic-calcic-nitrogenous multi-layer solid composites $(\mathrm{H}: \mathrm{Ca}: \mathrm{N}=1: 12: 15)$

(b), for humic-calcic-potassic-nitrogenous multi-layer solid composites (H:Ca:K:N=1:5:8:15) (c). I - for time $\bar{\tau}=0.027$; II - for time $\bar{\tau}=0.513 ; \mathrm{III}-$ for time $\bar{\tau}=0.918$

The given mass distribution of the granulated product for various types of the humic-mineral fertilizers for relative time $. \bar{\tau}=0.027, \bar{\tau}=0.513, \bar{\tau}=0.918$ shows the difference of the obtained dispersed composition from the predetermined one.

\section{Results and Discussion}

Based on the results of the experimental researches of the kinetics of granulation for humic-nitrogenous, humiccalcic-nitrogenous, and humic-calcic-potassic-nitrogenous multi-layer solid composites the dependence coefficients for the definition of product quality degradation were obtained. The coefficient definitions and the quality degradation equation are shown in Table 1.

Comparing the values of the coefficients $b$ allows to conclude that the best value $\sigma$ is observed for humicnitrogenous fertilizers, $b_{\sigma}=0.53$ (vide Table 1 ). In two other cases corresponding changes have been observed. Similarly it is possible to make conclusions concerning asymmetry and excess of the mass distribution of the granulated product for each relative time value.

The dynamics of the change of the granulation coefficient $\psi$ and the quality degradation function $L=f(\bar{\tau})$ are represented in Fig. 2 . The granulation quality assessment 


\section{Quality degradation function for different types} of humic-mineral fertilizers

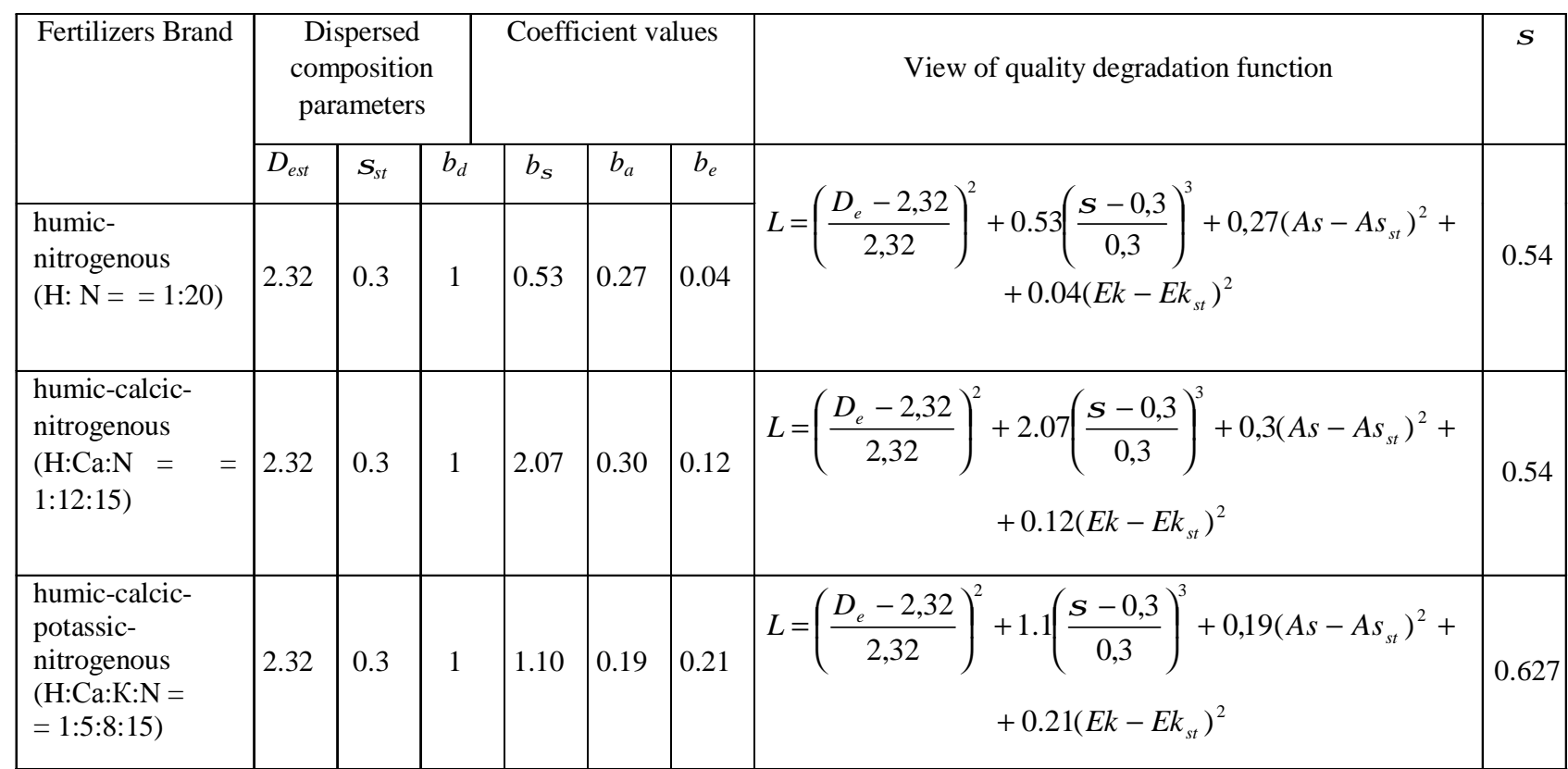

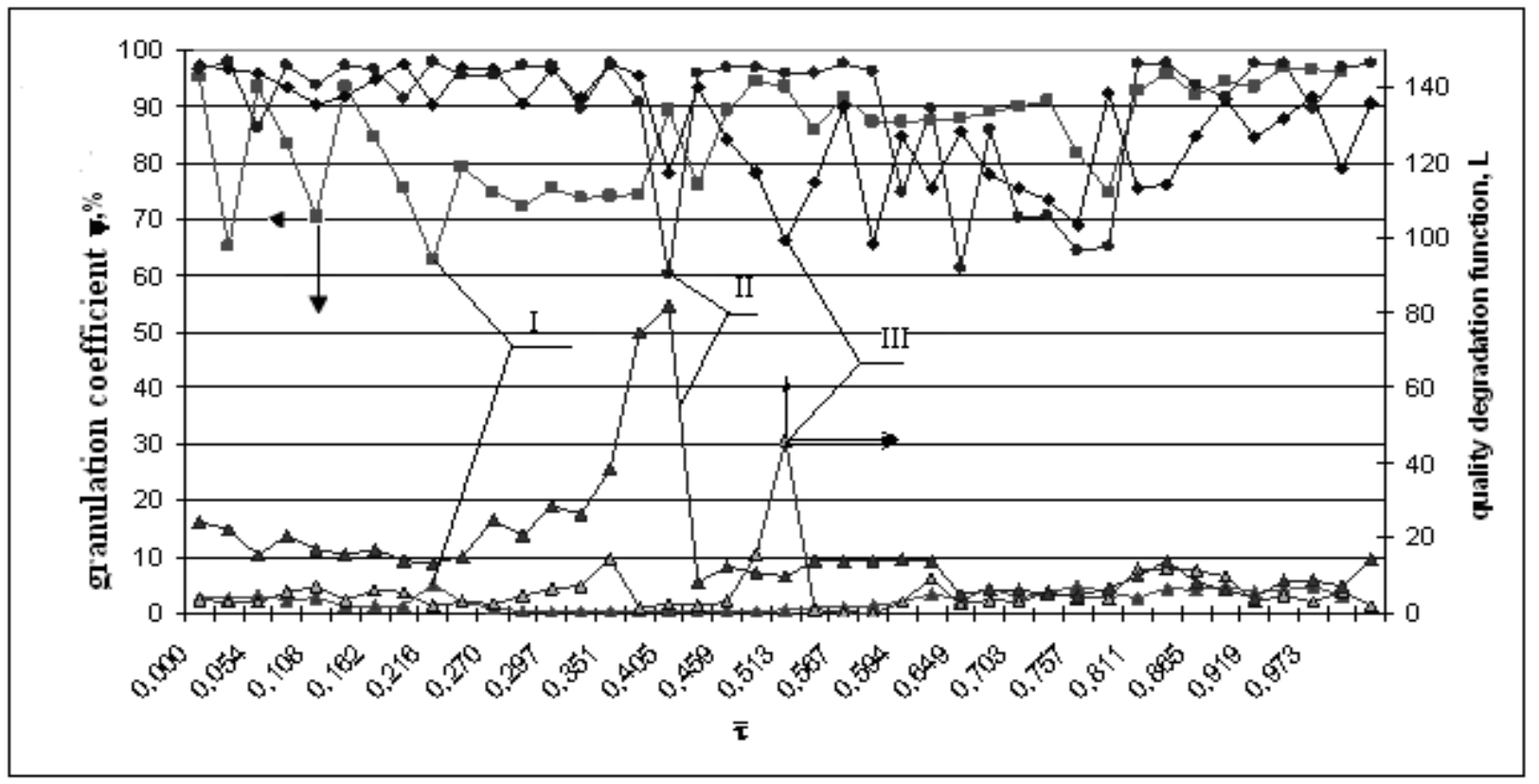

Fig. 2. Dynamics of the change of the quality degradation function and the granulation coefficient.

I - for the humic-nitrogenous multi-layer solid composites;

II - for the humic-calcic-nitrogenous multi-layer solid composites;

III - for the humic-calcic-potassic-nitrogenous multi-layer solid composites

of the humic-mineral solid composites will be defined by maximum values of $\psi$ and minimum values of $L$.

The presence of the extrema in the $L$ function indicates a significant defect in quality of the granulized product. However, the technological conditions when the minimum extrema of the dependence $\psi=f(\bar{\tau})$ coincides with the $L$ function extrema are most favorable for conducting the granulation process. 


\section{Conclusions}

Assess efficiency of the granulation multifactorial processes of complex humic-mineral fertilizers should be assessed both by the granulation coefficient $\psi \geq 85 \%$, as well as by the values of the $\mathrm{L}$ quality degradation function of the finished product $L$ when it approaches the minimum $-L<10$.

\section{References}

[1] Zagray Y. and Kornienko Y.: Pat. 4465 Ukraine. Published 27.12.94.

[2] Kornienko Y.: Visnyk Nats.Akad.Ukrainy, 2001, 3, 79.

[3] Kornienko Y.:Naukovi statti NTUU “KPI”, 2000, 2, 38.

[4] Kornienko Y., Statyukha G. and Skladanyy D.: Naukovi statti NTUU "KPI", 2002, 1, 133.
КОМПЛЕКСНА ОЦНКА ЕФЕКТИВНОСТІ ПРОЦЕСУ ГРАНУЛОУТВОРЕННЯ В ДИСПЕРСНИХ СИСТЕМАХ

Анотація: Запропоновано метод комплексної оцінки дисперсного складу гранульованого продукту, одержаного при гранулюванні з рідких систем для різних типів гуміновомінеральних багатотарових твердих композитів. Запропонована комплексна оцінка ефективності процесу за коефіцієнтом гранулоутворення та функиією втрат якості дисперсного складу гранульованого продукту.

Ключові слова: дисперсний склад, коефіиієнт гранулоутворення, функція втрат якості, гуміново-азотні, гуміново-кальцієво-азотні, гуміново-кальцієво-калійно-азотні багатошарові тверді композити. 